\title{
SÉRIE “Medycyny”
}

https://doi.org/10.52058/2695-1592-2021-1(1)-186-199

\section{Василій Єхалов}

кандидат медичних наук, дочент, доиент кафедри анестезіології, інтенсивної терапії та медицини невідкладних станів ФПО, «Дніпровський державний медичний університет», м. Дніпро, Украӥна, e-mail: sesualiy@gmail.com, https://orcid.org/0000-0001-5373-3820

\section{Ольга Кравець}

доктор медичних наук, дочент, завідуюча кафедрою анестезіології, інтенсивної терапії та медицини невідкладних станів ФПО, «Дніпровський державний медичний університет», м. Дніпро, Украйна, e-mail: 535951@ukr.net, https://orcid.org/0000-0003-1340-3290

\section{Наталія Башкірова}

кандидат медичних наук, доиент, доиент кафедры семейной медииины ФПО «Дніпровський державний медичний університет»,м. Дніпро, Украӥна, e-mail:bashkirovan@ukr.net, https://orcid.org/0000-0003-0716-2419

\section{Ольга Гайдук}

кандидат медичних наук, дочент, доиент кафедры семейной медииины ФПО «Дніпровський державний медичний університет», м. Дніпро, Україна, e-mail: olga.i.gayduk@gmail.com, https://orcid.org/0000-0003-0716-2419

\section{СИНДРОМ ЕМОЦЙНОГО ВИГОРЯННЯ НА ЕТАПАХ НАВЧАННЯ У ЛІКАРІВ 3 ФАХУ "ЗАГАЛЬНА ПРАКТИКА-СІМЕЙНА МЕДИЦИНА"}

Анотація. Синдром емоційного вигоряння серед лікарів є глобальною проблемою. Окрім психологічних змін особистості, цей стан призводить до фізичного нездужання. 
Метою дослідження було визначити динаміку розвитку синдрому емоційного вигоряння та оцінити ступінь його поширення серед студентів, які отримали розподіл, лікарів-інтернів та лікарів циклів вторинної спеціалізації за фахом "Загальна практика - сімейна медицина".

Проаналізовано 150 анонімних анкет студентів медичного університету, лікарів-інтернів та лікарів циклів вторинної спеціалізації за фахом "загальна практика - сімейна медицина". Опитування було проведене за методом В.В. Бойко. Визначалися наступні компоненти синдрому емоційного вигоряння: напруга, резистенція та виснаження.

Аналіз результатів анкетування зазначеного контингенту показав, що емоційне вигоряння починає формуватися ще на етапі додипломної освіти. Однак, ступені сформованості компонентів синдрому емоційного вигоряння i їх частота в найбільшій мірі зростають в процесі практичної професійної діяльності. У 16,7\% лікарів даного фаху прояви синдрому емоційного вигоряння характеризуються фазою виснаження, а у 33,3\% 3 них виснаження формується.

Ці факти підтверджують значну актуальність розробки системи профілактики емоційного вигоряння для лікарів загальної практики-сімейних лікарів на всіх етапах їх навчання і практичної роботи з метою надання ними якісної медичної допомоги населенню та збереження ефективного кадрового (лікарського) потенціалу.

Ключові слова: синдром емоційного вигоряння, лікарі загальної практики-сімейні лікарі.

\section{Vasily Ekhalov}

PhD, Associate Professor, Assistant Professor of the Department of Anesthesiology, Intensive Care and Medicine of Emergency Conditions, FPO, "Dnipro State Medical University", Dnipro, Ukraine, e-mail: sesualiy@gmail.com, https://orcid.org/0000-0001-5373-3820

\section{Olga Kravets}

MD, Professor, Head of the Department of the Department of Anesthesiology, Intensive Care and Medicine of Emergency Conditions, FPO, "Dnipro State Medical University", Dnipro, Ukraine, e-mail:535951@ukr.net, https://orcid.org/0000-0003-1340-3290 


\section{Nataliia Bashkirova}

PhD, Associate Professor, Assistant Professor of Family Medicine FPE "Dnipro

State Medical University", Dnipro, Ukraine, e-mail: bashkirovan@ukr.net, https://orcid.org/0000-0003-0716-2419

\section{Olga Haiduk}

PhD, Associate Professor, Assistant Professor of Family Medicine FPE "Dnipro State Medical University", Dnipro, Ukraine, e-mail: olga.i.gayduk@gmail.com, https://orcid.org/0000-0003-0716-2419

\section{EMOTIONAL BURNING SYNDROME AT THE STAGES OF TRAINING IN DOCTORS IN THE GENERAL PRACTICE-FAMILY MEDICINE}

Abstract. Emotional burnout syndrome among doctors is a global problem. In addition to psychological personality changes, this condition leads to physical illness.

The aim of the study was to determine the dynamics of the development of emotional burnout and assess the extent of its spread among students who received distribution, interns and doctors of secondary specialization in the specialty "General Practice - Family Medicine".

150 anonymous questionnaires of medical university students, interns and doctors of secondary specialization cycles in the specialty "general practice family medicine" were analyzed. The survey was conducted by the method of VV Boyko. The following components of the emotional burnout syndrome were determined: stress, resistance and exhaustion.

The analysis of the results of the questionnaire showed that emotional burnout in general practitioners-family doctors begins to form at the stage of undergraduate education. However, the degree of formation of the components of the emotional burnout syndrome and their frequency increase to the greatest extent in the process of practical professional activity. In $16.7 \%$ of physicians in this specialty, the manifestations of emotional burnout are characterized by a phase of exhaustion, and in $33.3 \%$ of them exhaustion is formed.

These facts confirm the significant relevance of developing a system of prevention of emotional burnout for general practitioners-family doctors at all stages of their training and practical work in order to provide them with quality medical care and maintain effective human (medical) potential.

Keywords: emotional burnout syndrome, general practitioners-family doctors. 
Постановка проблеми. За визначенням ВООЗ, синдром емоційного вигоряння - це фізичне, емоційне, або мотиваційне виснаження, що характеризується порушенням продуктивності в роботі, втомою, безсонням, підвищеною схильністю до соматичних захворювань, а також вживанням алкоголю або інших психоактивних речовин для отримання тимчасового полегшення, що має тенденцію до розвитку фізичної залежності та навіть суїцидальної поведінки. Цей синдром розцінюється як стрес-реакція на тривалі виробничі та емоційні вимоги, які виникають унаслідок надмірної відданості людини своїй роботі з одночасним нехтуванням сімейним життям, власним здоров'ям та відпочинком. За Міжнародною класифікацією хвороб Х перегляду, цей стан належить до рубрики «Стрес, пов'язаний з труднощами підтримки нормального способу життя» [1].

Аналіз останніх досліджень та публікацій. До найбільшого ризику розвитку синдрому професійного вигоряння схильні медичні працівники. Синдром формується ще на додипломному етапі освіти, триває протягом усього періоду резидентури i проявляється у повсякденному житті практикуючих лікарів. Так, за даними J. Cecil et al. (2014), у студентівмедиків високий рівень емоційного виснаження (EB) присутній у 54,8\% випадків; підвищений рівень деперсоналізації (ДП) - у 34,0\% опитаних; високий рівень редукції професійних досягнень (РПД) - у 46,6\% респондентів [2].

Особливість роботи лікаря загальної практики-сімейного лікаря полягає в тому, що він працює самостійно і несе основну відповідальність за забезпечення безперервної кваліфікованої медичної допомоги кожному пацієнту незалежно від віку та статі, віросповідання, характеру захворювання тощо [3]. За даними вітчизняних та закордонних авторів сімейні лікарі мають один 3 найвищих рівнів професійного вигоряння серед медичних працівників. Фактори, що сприяють виникненню цього стану серед лікарів первинної ланки, включають: значне робоче навантаження, брак часу i ресурсів, постійний контакт зі «складними» пацієнтами та їх родичами, адміністративний тиск. Встановлено, що до 45,8\% лікарів повідомляли хоча б про один симптом вигоряння. У дослідженні European General Practice Research, у якому брали участь 1400 сімейних лікарів з 12 країн, до 43\% мали хоча б один параметр синдрому, а 12\% страждали від вигоряння в усіх 3 вимірюваннях [4].

Синдром емоційного вигоряння в медичному середовищі та серед сімейних лікарів, зокрема, являє собою проблему всесвітнього масштабу. Фізичне та психічне виснаження, що виникає у працюючих у стресовому середовищі, діагностовано у 50\% всіх медпрацівників та у $63 \%$ сімейних лікарів США, і ця цифра поступово зростає. Навіть при роботі у задовільних умовах до $40 \%$ американських лікарів повідомляли про те, що мають 
симптоми вигоряння [5,6]. ]. Опитування з цієї проблеми серед лікарів первинної ланки (Південна Африка) показало, що 27\% респондентів страждали на депресію середнього ступеня тяжкості, 76\% мали високий рівень вигоряння [7], а у Сполучених Штатах Америки - цей показник був меншим - 42,3\% [8]. Результати інших досліджень, що були опубліковані у доступних літературних джерелах, наведені у табл.1.

Таблиия 1.

Результати дослідження складових синдрому емоційного вигоряння у лікарів загальної практики-сімейних лікарів у різних країнах

\begin{tabular}{|c|c|c|c|}
\hline Країна & $\begin{array}{l}\text { Емоційне } \\
\text { виснаження }\end{array}$ & $\begin{array}{l}\text { Деперсоналі } \\
\text { зація }\end{array}$ & $\begin{array}{l}\text { Професійне } \\
\text { вигоряння }\end{array}$ \\
\hline $\begin{array}{l}\text { Україна: Ужгород та } \\
\text { Краматорськ }[1,10]\end{array}$ & $83 \%$ & $94 \%$ & $88 \%$ \\
\hline $\begin{array}{l}\text { Україна: } \\
\text { Дніпровський регіон } \\
\text { [11] }\end{array}$ & $38 \%$ & $84 \%$ & $40 \%$ \\
\hline Свропа (12 країн) [12] & $43 \%$ & $35 \%$ & $32 \%$ \\
\hline Емірат Кувейт [13] & $19 \%$ & $27 \%$ & $33 \%$ \\
\hline США: Техас [14] & $39 \%$ & $27,1 \%$ & $37,7 \%$ \\
\hline $\begin{array}{l}\text { Королівство } \\
{[15,16]}\end{array}$ & $30 \%$ & $19 \%$ & $50 \%$ \\
\hline $\begin{array}{l}\text { Королівство } \\
\text { Саудівська Аравія [17] }\end{array}$ & $29,5 \%$ & $15,7 \%$ & $19,7 \%$ \\
\hline $\begin{array}{l}\text { Сербська Республіка } \\
{[18]}\end{array}$ & $29,7 \%$ & $25,7 \%$ & $37,8 \%$ \\
\hline Султанат Оман [19] & $17,8 \%$ & $38,2 \%$ & $21,5 \%$ \\
\hline $\begin{array}{l}\text { Португальська } \\
\text { Республіка [20] }\end{array}$ & $25,3 \%$ & $16,2 \%$ & $16,7 \%$ \\
\hline Емірат Катар [21] & $59,7 \%$ & $36,1 \%$ & $31,2 \%$ \\
\hline $\begin{array}{l}\text { Французька } \\
\text { Республіка [19] }\end{array}$ & $16 \%$ & $34 \%$ & $40 \%$ \\
\hline
\end{tabular}

Мета статті: вивчити динаміку розвитку синдрому емоційного вигоряння на етапах навчання лікарів за фахом "Загальна практика - сімейна медицина", оцінити ступінь поширення даного процесу серед студентів медичного університету, які отримали розподіл за спеціальністю, лікарів інтернів та лікарів циклів вторинної спеціалізації, намітити шляхи попередження і профілактики професійного вигоряння.

Виклад основного матеріалу. Проаналізовано 150 анонімних анкет студентів медичного університету, лікарів-інтернів та лікарів-слухачів циклу вторинної спеціалізації за фахом "загальна практика - сімейна медицина". Було проведене опитування за методом В.В. Бойко, коли респондентам пропонували відповісти на 84 питання за принципом «так» або «ні». Визначалися компоненти синдрому: напруга, резистенція та виснаження. При цьому показник вираженості кожного симптому оцінювався як 
несформований симптом при 9 i менше сумарних балів, симптом, що формується - при 10-15 балах та сформований - при 16 та більше балів [9, 10].

Результати та обговорення. Процес навчання потенційно також містить у собі небезпеку розвитку синдрому емоційного вигоряння (СЕВ). На молодших курсах стан спричиняється стресом переходу від суто навчальної діяльності до навчально-професійної, у студентів-випускників вищих навчальних закладів може виникнути невпевненість у виборі професії та можливостях подальшої самореалізації. Певна частка майбутніх фахівців повинна працювати у нічний час для матеріального забезпечення життя i навчання. Все це може прислужитися факторами, що провокують стан емоційного вигоряння $[9,11]$.

Бойко В.В. розглядає професійне вигоряння 3 позицій загального адаптаційного синдрому Селье Г. [10] визначають 3 стадії розвитку вигоряння, кожна з яких проявляється у вигляді 4 симптомів:

1. Фаза напружсення. Наявність настороженості служить провісником розвитку i запускає механізм формування СЕВ. Тривожне напруження включає наступні симптоми: переживання психотравмуючих обставин, незадоволеність собою, «загнанність до клітки» (виникає не завжди, характеризується відчуттям безвиході, безнадії, тривоги та депресії).

2. Фаза резистентності. Визначення цієї фази як самостійної вельми умовне. При усвідомленні наявності тривожного напруження людина прагне уникати впливу афективних чинників за допомогою обмеження емоційного відгуку: неадекватного виборчого емоційного реагування, емоційноморальної дезорієнтації, розширення сфери економії емоцій, редукції професійних обов'язків.

3. Фаза виснаження. Характеризується падінням загального енергетичного тонусу та знесиленням нервової системи: емоційний дефіцит, емоційна відстороненість, особистісна відстороненість (деперсоналізація), психосоматичні та вегетативні прояви [1, 10, 12].

Емоційне вигоряння Бойко В.В. визначає як створений особистістю механізм психологічного захисту у формі повного або часткового виключення емоцій (зниження їх енергетики) у відповідь на психотравмуючі агенти. Вигоряння він вважає набутим функціональним стереотипом емоційної, частіше професійної, поведінки, що дозволяє людині дозовано та економно витрачати енергетичні ресурси. Цей процес автор характеризує як конструктивний, а дисфункціональними вважає його наслідки, коли «вигоряння» негативно позначається на виконанні професійних обов'язків та міжособистісних відносинах. Тоді емоційне вигоряння призводить до професійної деформації [10].

Зустріч зі смертю, стражданнями та іншими емоційними навантаженнями сприяє виникненню студентського вигоряння. 3 іншого боку - це збільшення обсягу необхідної для вивчення інформації, введення нових форм контролю (іспити, заліки, тестування). В умовах пандемії Covid - 19 у 
майбутніх колег з'являється постійне відчуття неспокою, невизначеності, "синдрому жертви". Встановлено, що вигоряння серед студентів-медиків вище, ніж у їхніх однолітків інших спеціальностей [13]. Цей процес активується 3 продовженням навчання: ступень тяжкості за всіма показниками вигоряння більше у клінічному, ніж у доклінічному періоді [14]. Отримані у нашому дослідженні результати аналізу анонімних анкет студентів, інтернів та лікарів вторинної спеціалізації наведені у табл. 2.

Таблицяя 2

Ступені сформованості компонентів синдрому емоційного вигоряння на етапах навчання за фахом "Загальна практика-сімейна медицина"

\begin{tabular}{|c|c|c|c|c|}
\hline \multirow{2}{*}{$\begin{array}{l}\text { Компо } \\
\text { ненти } \\
\text { вигоряння }\end{array}$} & \multirow{2}{*}{$\begin{array}{l}\text { Суб'скти } \\
\text { навчання }\end{array}$} & \multicolumn{3}{|c|}{ Ступень сформованості } \\
\hline & & $\begin{array}{l}\text { Не сфор- } \\
\text { мований }\end{array}$ & $\begin{array}{l}\text { Той, що } \\
\text { формусться }\end{array}$ & $\begin{array}{l}\text { Сформо- } \\
\text { ваний }\end{array}$ \\
\hline \multirow[t]{3}{*}{ Напруження } & Студенти & $45,8 \%$ & $24,0 \%$ & $30,2 \%$ \\
\hline & Інтерни & $45,6 \%$ & $24,1 \%$ & $30,3 \%$ \\
\hline & $\begin{array}{l}\text { Лікарі вторинної } \\
\text { спеціалізації }\end{array}$ & $41,7 \%$ & $25,0 \%$ & $33,3 \%$ \\
\hline \multirow[t]{3}{*}{ Резистенція } & Студенти & $46,5 \%$ & $23,1 \%$ & $30,4 \%$ \\
\hline & Інтерни & $39,6 \%$ & $22,1 \%$ & $38,3 \%$ \\
\hline & $\begin{array}{l}\text { Лікарі вторинної } \\
\text { спеціалізації }\end{array}$ & $33,3 \%$ & $25,0 \%$ & $41,7 \%$ \\
\hline \multirow[t]{3}{*}{ Виснаження } & Студенти & $72,6 \%$ & $16,3 \%$ & $11,1 \%$ \\
\hline & Інтерни & $51,5 \%$ & $32,1 \%$ & $16,4 \%$ \\
\hline & $\begin{array}{l}\text { Лікарі вторинної } \\
\text { спеціалізації }\end{array}$ & $50,0 \%$ & $33,3 \%$ & $16,7 \%$ \\
\hline
\end{tabular}

Сформований ступень напруження спостерігається ще на етапі додипломного навчання при наявності досить високого ступеня формування, у подальшому ці показники незначно прогресують. При цьому у переважної більшості опитаних домінуючими симптомами були переживання психотравмуючих обставин, тривога та депресія.

Найвищий ступень сформованої резистенції показали лікарі вторинної спеціалізації, що пояснюється дією захисного психологічного механізму, оскільки зміна спеціальності у поважному віці провокує неабияку стресову ситуацію, у лікарів-інтернів цей показник трохи нижчий, а у студентів менший на чверть. Формування цієї складової емоційного вигоряння в усіх групах дослідження знаходиться на досить високому рівні. Звертає на себе увагу, що в усіх групах домінуючим симптомом (у значному кількісному відриві від інших) $є$ неадекватне вибіркове емоційне реагування. У наших 
попередніх роботах ми торкалися соціально-психологічної характеристики сучасної молоді [3, 9]. Надвисока самооцінка, практично повна некомпетентність у виробничих міжособистісних відносинах, бажання отримувати швидкий результат тощо є основними рисами образу сучасного інтерна, та в умовах, коли йому щось не вдається, тоді виникає стресова ситуація.

Сформований ступень виснаження на перший погляд здається незначним, але спричиняє занепокоєність значне зростання показників формування цієї фази при вторинній та навіть первинній спеціалізації, залишаючись значно нижчим на етапі додипломної освіти.

При порівнянні отриманих нами даних 3 результатами дослідження Vysochina, I.L., Kramarchuk, V.V. (2019) у лікарів загальної практики сімейних лікарів Дніпровського регіону з певним стажем практичної роботи [15] можна зробити висновок, що емоційне вигоряння у більшій мірі формується не на етапах навчання, а під час практичної роботи. Приєднуються ознаки емоційного виснаження. Всі отримані авторами показники складових синдрому перевищують наші результати, здебільшого за рахунок деперсоналізації.

Синдром професійного емоційного вигоряння на різних етапах навчання та підвищення кваліфікації медичних працівників являє собою серйозну проблему сьогодення. Окрім психологічних змін особистості, цей стан призводить до фізичного нездужання. Причинами поширення синдрому $\epsilon$ збільшення емоційної та фізичної напруги лікарів для забезпечення виконання своїх професійних обов'язків [9]. Наслідком емоційного вигоряння $\epsilon$ такий негативний прояв професійної діяльності, як стандартизація спілкування, застосування в роботі стереотипних навичок, неодноразових шаблонів, підміна творчої продуктивної діяльності формальним виконанням своїх обов'язків, бажання знизити обсяг роботи, бо лікарю у цьому стані здається, що його відчуття хронічної втоми та напруження пов'язані 3 перенавантаженням. У нього з'являється бажання усуватися від додаткових стресів, збільшувати дистанцію у спілкуванні з пацієнтами та колегами, уникати нових обов'язків [12]. Встановлено, що лікарі, які мають синдром професійного вигоряння, роблять велику кількість медичних помилок i подекуди надають пацієнтам неякісну медичну допомогу [16].

Лікарям загальної практики - сімейним лікарям притаманне високе почуття емпатії, тобто співчуття, співпереживання, що для медичних працівників є необхідною професійною якістю [17]. Для допомагаючої професійної діяльності, до якої традиційно відносять роботу сімейних лікарів, характерно, що у більшості ситуацій лікар взаємодіє з фізично або морально страждаючою людиною. При цьому дії, що здатні припинити або полегшити страждання іншої людини, включені до його посадових обов'язків. У фахівця немає вибору, допомагати або не допомагати, як це можливо в нашому повсякденному житті. Не тільки у популярній, але й у науковій літературі досить часто стверджується, що ненавмисне емоційне 
зараження станом іншої людини, практично не піддається регулюванню, i в результаті висока схильність до емпатії обов'язково призводить фахівця допомогаючої професії до вигоряння [18, 19]. Відмічено, що рівень емпатії студентів-медиків знижується за мірою їх проходження курсу навчання. Багато 3 них стають емоційно відключеними від людей, про яких вони піклуються, - i це роз'єднання може завдати шкоди догляду. Низьке співчуття, мабуть, пов'язано 3 сильним вигорянням, особливо 3 деякими компонентами синдрому [20, 21, 22]. Чи так це? У наших попередніх дослідженнях [23] ми визначили досить значний рівень професійної емпатії у лікарів-інтернів різних спеціальностей, що навчалися за циклом "Невідкладні стани". Навпаки, виявлена Карягіною Т.Д. та співавт. (2017) відсутність зв'язку симптомів вигоряння 3 високим рівнем емпатії «дестигматизує» допомагаючих професіоналів, робота яких часто роздивляється через призму уявлення про неминучість вигоряння у високоемпатичних осіб. На перший план виходить проблема професіоналізації емпатії як розвитку іiі регуляції. Проведений аналіз «симптомокомплексу позитивних емпатичних феноменів» та «симптомокомплексу особистого дистресу» дозволяє намітити можливі «мішені» тренінгу, програми супроводу та супервізії фахівців [24]. Поєднання високого ступеня емпатії 3 низьким рівнем самовигоряння $\epsilon$ оптимальним сполученням характеристик сучасного сімейного лікаря. Більш того, співчуття пацієнтові може служити профілактичним фактором для розвитку цього синдрому [20].

Як було сказано раніше, самовигоряння лікарів первинної ланки являє собою важливу сучасну проблему світового масштабу. Згідно 3 даними ФДБУ «Національного наукового центру наркології» (2012) визначена тенденція може незабаром призвести або до скорочення кількості сімейних лікарів, які раніше підуть 3 професії, або до скорочення їх робочих годин, в той час як потреба у цій професії у США постійно зростає 3 причини постаріння населення [21].

У цивілізованих країнах права лікаря закріплені законодавством. Акцент зроблено на адекватність розміру винагороди лікаря відповідно до його праці. Крім цього, у США, Канаді, Франції допомогу лікарям надають неурядові суспільства, асоціації лікарів. Наприклад, спільними зусиллями американської та канадської медичних асоціацій кожні два роки проводиться Міжнародна конференція зі здоров'я лікарів. Існують проекти "Відроджуйся!" Американської колегії лікарів та Американського товариства внутрішньої медицини та ряду інших організацій. Дуже важливо відзначити, що передбачається комплексна підтримка лікаря: соціальна, психологічна, а також правова - вже на етапі студентства. На Заході абітурієнти вищих навчальних медичних закладів проходять тести на визначення схильності до емоційного вигоряння.

Слід зазначити, що стрімкий науково технічний прогрес, зворотна сторона якого - постійне напруження, стреси, перевантаження, дефіцит часу, переінформірованность та інші небажані інциденти, поряд зі сформованими 
несприятливими соціально-економічними факторами, вираженість яких в нашій країні 3 кожним роком збільшується, супроводжується зростанням невротизації та психопатизації населення, що в комплексі робить суспільство більш агресивним [26]. Фахівець відчуває невдоволеність своїми професійними якостями, невідповідністю матеріальної винагороди докладеним зусиллям, зубожінням культури спілкування населення, приниженням гідності професії лікаря, що штучно підсилюється некомпетентними співробітниками 3МI та популістськими керівними рішеннями при збільшеному навантаженні на лікарську особу в порівнянні 3 таким у нещодавній час. Цей стан досить часто призводить до фізичного нездужання [27], зниження імунітету. Тобто потрібні термінові профілактичні заходи.

У чималій мірі успіхи навчальних програм, особливо тренінгових, пов'язані з тим, що люди, які приходять у ці групи, вже орієнтовані на особисті зміни та на сприйняття нового. Навчати людей новій поведінці реально тільки в тому випадку, якщо вони самі схочуть змінитися. Питання в тому, як спонукати до змін тих, хто не схильний до цього.

Не секрет, що більшість вітчизняних лікарів недостатньо опікуються власним здоров'ям. Під час пандемії Covid-19 їх психічне та фізичне навантаження значно зросло: майже тотальна вірогідність зараження; нагальна потреба замінити колег, що захворіли. Переважна кількість сімейних лікарів не мають фізичної можливості відвідувати тренінги, що вимагають особистої присутності. Знизити особисте навантаження на лікаря у наш час - взагалі утопічне припущення. Забезпечити адекватний відпочинок в умовах пандемії не тільки малореально, але й небезпечно. На жаль, після проведеного дослідження виникло більше питань, ніж було знайдено відповідей.

\section{Висновки:}

1. Розвиток і прогресування синдрому емоційного вигоряння серед лікарів загальної практики - сімейних лікарів $\epsilon$ надзвичайно важливою проблемою.

2. Емоційне вигоряння у лікарів даного фаху починає формуватися на етапі додипломної освіти.

3. Під час практичної професійної діяльності 50,0\% лікарів загальної практики-сімейних лікарів мають прояви синдрому емоційного вигоряння в фазі виснаження (16,7\%) або його формування $(33,3 \%)$.

4. Значну актуальність для лікарів загальної практики має розробка системи профілактики емоційного вигоряння на всіх етапах їх навчання i практичної роботи 3 метою надання ними якісної медичної допомоги населенню та збереження ефективного кадрового (лікарського) потенціалу.

Конфлікт інтересів. Автори заявляють про відсутність конфлікту інтересів та власної фінансової зацікавленості при підготовці даної статті. 


\section{Лimepamypa:}

1. Ровенська В. В., Саржевська Є. О. Особливості розвитку та проявів синдрому емоційного вигорання у лікарів //Економічний вісник Донбасу. - 2020. - №. 1 (59). C. 123-129-123-129. doi: https://doi.org/10.12958/1817-3772-2020-1(59)-123-129

2. Cecil J. et al. Behaviour and burnout in medical students //Medical education online. 2014. - T. 19. - №. 1. - C. 25209.

3. Клигуненко Е. Н. и др. Клиповое мышление в анестезиологии: катастрофа или закономерность? //Медицина неотложных состояний. - 2019. - №. 3 (98). С. 111-123. doi: 10.22141/2224-0586.3.98.2019.165488

4. Chee Lian L.N. The Singapore Family Physician. - 2016. - v. 4. № 2(1). P. 6-12.

5. Puffer J. C. et al. Prevalence of burnout in board certified family physicians //The Journal of the American Board of Family Medicine. - 2017. - T. 30. - №. 2. - C. 125-126. doi: 10.3122 /jabfm.2017.02.160295

6. American Academy of Family Physicians et al. Family physician burnout, well-being, and professional satisfaction. - 2018 - $\quad$ Режим доступу: https://www.aafp.org/about/policies/all/family-physician-burnout.html

7. Wagner L., Pather M. K. Exploring resilience in family physicians working in primary health care in the Cape Metropole //African journal of primary health care \& family medicine. 2019. - T. 11. - №. 1. - C. 1-10. doi: https://doi.org/10.4102/phcfm.v11i1.1982

8. Pereda-Torales L. et al. Burnout syndrome in medical practitioners and paramedic personel //Salud mental. - 2009. - T. 32. - №. 5. - C. 399-404.

9. Схалов В. В. и др. Синдром емоційного вигоряння в медичній післядипломній освіті //Новини медицини та фармації. - 2021. - Т. 4. - С. 13.

10. Бойко В. В. Энергия эмоций. СПб. : Питер, 2004. 474 с.

11. Беззубцева Н.О., Петрова И.В. Синдром эмоционального выгорания у студентов ВУЗа. Материалы XI Международной студенческой научной конференции «Студенческий научный форум», 2019. URL:<ahref="https://scienceforum.ru/2019/article/2018011149"> https://scienceforum.ru/2019/article/2018011149.

12. Пащенко М. В., Куташов В. А. К проблеме эмоционального выгорания у врачей //Молодой ученый. - 2015. - №. 23. - С. 368-370. URL: https://moluch.ru /archive/103/23870/

13. Dyrbye L. N. et al. Burnout among US medical students, residents, and early career physicians relative to the general US population //Academic medicine. - 2014. - T. 89. - №. 3. C. 443-451. doi : 10.1097/ ACM.0000000000000134

14. Хайрушева Д. А., Белтенова А. Г. Проблема профессионального выгорания в деятельности медицинских работников (обзор) //Наука о жизни и здоровье. -2017 . - №. 3 .

15. Vysochina, I.L. и Kramarchuk, V.V. Professional burnout syndrome among family doctors of Dnipropetrovsk region. In: Modern methods of diagnostics and treatment: experience of EU countries (27-28 december). Lublin, 2019. P. 206-208.

16. Williams E. S. et al. The relationship of organizational culture, stress, satisfaction, and burnout with physician-reported error and suboptimal patient care: results from the MEMO study //Health care management review. - 2007. - T. 32. - №. 3. - C. 203-212.

17. Малик Н. В. Деякі психологічні аспекти взаємовідносин сімейного лікаря i пацієнта //Семейная медицина. - 2016. - №. 2. - С. 25-26.

18. Мартьянова М. А. Эмпатия и выгорание (на примере специалистов коммуникативных профессий). Владивосток, 2018. 76 с.

19. Головенко Х. В. Сопель О. Поширеність синдрому емоційного вигорання у медичного персоналу і фактори, які спричиняють його розвиток.// Медсестринство. 2017. - № 4. - C. 51-53.

20. Yuguero O. et al. Occupational burnout and empathy influence blood pressure control in primary care physicians //BMC Family Practice. - 2017. - T. 18. - №. 1. - C. 1-9. doi: 10.1186/s12875-017-0634-0 
21. Montero-Marin J. et al. Burnout subtypes and absence of self-compassion in primary healthcare professionals: A cross-sectional study //PloS one. -2016 . - T. 11. - №. 6. - C. e0157499. doi:10.1371/journal.pone.0157499. eCollection 2016.

22. Захарова Е. А., Ежова Ю. М., Раков Н. А. Эмпатия как основа коммуникации врач-пациент: современное состояние проблемы //Психология. Историкокритические обзоры и современные исследования. - 2019. - Т. 8. - №. 3-1. - С. 119-138..

23. Yekhalov V. V., Kravets O. V., Krishtafor D. A. Psychological Features of the Modern Intern //The world of science and innovation. Abstracts of the 6th International scientific and practical conference. - Cognum Publishing House, 2021. - C. 304-311.

24. Карягина Т. Д. и др. Профессионализация эмпатии и предикторы выгорания помогающих специалистов //Консультативная психология и психотерапия. - 2017. - Т. 25. - №. 2. - С. 39-58. doi:10.17759/cpp.2017250203

25. Говорин Н.В., Бодагова Е.А. Синдром эмоционального выгорания у врачей.// ОРГЗДРАВ: Новости, мнения, обучение. - 2016. - № 1 (3). - С. 98-106.

26. Усенко Л.В., Кобеляцкий Ю.Ю., Клопоцкая Н.Г., Царев А.В., Усенко А.А., Оленюк Д.В. Конфликтные ситуации в медицинской практике: этические и правовые аспекты.// Медицина невідкладних станів. - 2020. - т. 16. - № 1. - С. 115-119. doi: 10.22141/2224-0586.16.1.2020.196939

27. Васильев В. Ю., Пушкаренко И. А. Причины развития" эмоционального выгорания" у анестезиологов-реаниматологов //Общая реаниматология. - 2011. - Т. 7. №. 2. - C. 66-70. doi:10.15360/1813-9779-2011-2-66.

\section{References:}

1. Rovensjka, V. V. \& Sarzhevsjka, Je. O. (2020). Osoblyvosti rozvytku ta projaviv syndromu emocijnogho vyghorannja u likariv [Features of development and manifestations of emotional burnout syndrome in doctors]. Ekonomichnyj visnyk Donbasu - Economic Herald of the Donbas, 1(59), 123-129 [in Ukrainian].

2. Jo Cecil, Calum McHale, Jo Hart \& Anita Laidlaw (2014). Behaviour and burnout in medical students, Medical Education Online, 19, 1 [in English].

3. Klyhunenko, O. M., Yekhalov, V. V., Kushch, K. O., Kravets, O. V., Haiduk, O. I. H., Barannik, S. I., et al. (2019). Klipovoe myshlenie v anesteziologii: katastrofa ili zakonomernost? [Mosaic thinking in anesthesiology: catastrophy or regularity?]. Meditsina neotlozhnykh sostoyaniy - Emergency medicine, (3.98), 111-123. [in Ukrainian].

4. Lim, K. S., Chia, Z. J., Myint, M. Z., Ara, K. J., Chee, Y. C., Heng, W. T. \& Tan, C. T. (2020). Epilepsy in Southeast Asia, how much have we closed the management gap in past two decades?. Neurology Asia, 25(4) [in English].

5. Puffer, J. C., Knight, H. C., O'Neill, T. R., Rassolian, M., Bazemore, A. W., Peterson, L. E., \& Baxley, E. G. (2017). Prevalence of burnout in board certified family physicians. The Journal of the American Board of Family Medicine,30(2), 125-126. doi: 10.3122 /jabfm.2017.02.160295 [in English].

6. American Academy of Family Physicians. (2018). Family physician burnout, well-being, and professional satisfaction. Retrieved from https://www.aafp.org/about/policies/all/family-physicianburnout.html [in English].

7. Wagner, L., \& Pather, M. K. (2019). Exploring resilience in family physicians working in primary health care in the Cape Metropole. African journal of primary health care $\&$ family medicine, 11(1), 1-10. [in English].

8. Pereda-Torales, L., Marquez Celedonio, F. G., Hoyos Vasquez, M. T., \& Yanez Zamora, M. I. (2009). Burnout syndrome in medical practitioners and paramedic personel. Salud mental, 32(5), 399-404. [in English].

9. Jekhalov, V. V., Kravecj, O.V., Kryshtafor, D.A., Stanin, D.M. \& Khobotova, N.V. (2021). Syndrom emocijnogho vyghorjannja u medychnij pisljadyplomnij osviti [Emotional burnout syndrome in medical postgraduate education]. Novyny medycyny ta farmaciji-Medicine 
and Pharmacy News, 4(751), 13 [in Ukrainian].

10. Boyko V.V. Energy of emotions [Energiy aemotsii]. SPb. Piter, 2009, 474 [in Russian].

11. Bezzubtseva, N.O., Petrova, I.V. (2019). Sindrom emotsionalnogo vygoraniya u studentov VUZa. [Burnout syndrome in university students.] Materialy XI Mezhdunarodnoy studencheskoy nauchnoy konferentsii «Studencheskiy nauchnyy forum»-Materials of the XI International Student Scientific Conference "Student Scientific Forum".pp [in Russian]

12. Pashchenko, M.V. \& Kutashov, V.A. (2015). K probleme emotsionalnogo vygoraniya $\mathrm{u}$ vrachey [ To the problem of emotional burnout in doctors]. Molodoy uchenyy Young scientist, 23 (103), 368-370 [in Russian].

13. Dyrbye L.N., West C.P., Satele D. et al. (2014). Burnout among U.S. medical students, residents, and early career physicians relative to the general U.S. population Academic Medicine, 89(3), 443-51 [in English].

14. Khayrusheva, D.A. \& Beltenova, A.G. (2017). Problema professionalnogo vygoraniya $\mathrm{v}$ deyatelnosti meditsinskikh rabotnikov (obzor) [The problem of professional burnout in the activities of medical workers (review)]. Vestnik AGIUV - Messenger AGIUV, 3, 77-85 [in Russian].

15. Vysochina, I.L. \& Kramarchuk, V.V. (2019). Professional burnout syndrome among family doctors of Dnipropetrovsk region. In: Modern methods of diagnostics and treatment: experience of EU countries (27-28 december). Lublin, 206-208. [in English].

16. Williams E. S., Manwell L. B., Konrad T. R. \& Linzer M. Health Care Manage Review, (2007). The relationship of organizational culture, stress, satisfaction, and burnout with physician-reported error and suboptimal patient care: results from the MEMO study, 32. 203212. [in English].

17. Malyk, N. V. (2016). Deiaki psykholohichni aspekty vzaiemovidnosyn simeinoho likaria i patsiienta [Some psychological aspects of the relationship between family doctor and patient]. Semeinaia medytsyna - Family medicine, (2), 25-26 [in Ukrainian].

18. Martyanova, M.A. (2011). Empatiya i vygoranie (na primere spetsialistov kommunikativnykh professiy) [Empathy and burnout (on the example of specialists in communication professions)]. Vladivostok [in Russian].

19. Holovenko, Kh. V. \& Sopel, O. (2017). Poshyrenist syndromu emotsiinoho vyhorannia u medychnoho personalu i faktory, yaki sprychyniaiut yoho rozvytok [The prevalence of emotional burnout in medical staff and the factors that cause its development]. Medsestrynstvo - Nursing, 4. 51-53 [in Ukrainian].

20. Yuguero O., Marsal J.R. , Esquerda M. et al. (2017). Occupational burnout and empathy influence blood pressure control in primary care physicians, BMC Family Practice, 18:63. 2-9. [in English].

21. Montero-Marin J., Zubiaga F., Cereceda M. et al. Plos One. United States, (2016). Burnout Subtypes and Absence of Self-Compassion in Primary Healthcare Professionals: A Cross- Sectional Study, 11, 6, e0157499 [in English]. 22. Zakharova, Ye.A., Yezhova, Yu.M. \& Rakov, N.A. (2019). Empatiya kak osnova kommunikatsii vrach-patsient: sovremennoe sostoyanie problemy [Empathy as the basis of doctor-patient communication: the current state of the problem]. Psikhologiya. Istoriko-kriticheskie obzory $i$ sovremennye issledovaniya.Psychology. Historical and critical reviews and modern research, 8, 3A, 119-138 [in Russian].

23. Yekhalov, V.V., Kravets, O.V. \& Krishtafor, D. A., (2021). Psychological Features of the Modern Intern. The world of science and innovation. Abstracts of the 6th International scientific and practical conference. Cognum Publishing House. London, United Kingdom, 304311. [in English].URL: https://sci-conf.com.ua/vi-mezhdunarodnaya-nauchno-prakticheskayakonferentsiya-the-world-of-science-and-innovation-14-16-yanvarya-2021-goda-london-

velikobritaniya-arhiv/

24. Karyagina, T.D., Kukhtova, N.V., Olifirovich, N.I. \& Shermazanyan L.G. (2017). Professionalizatsiya empatii i prediktory vygoraniya pomogayushchikh spetsialistov 
[Professionalization of empathy and predictors of helping professionals' burnout]. Konsultativnaya psikhologiya i psikhoterapiya - Counseling Psychology and Psychotherapy, 25, 2, 39-58 [in Russian].

25. Govorin, N.V. \& Bodagova, Ye.A. (2016). Sindrom emotsionalnogo vygoraniya u vrachey. [Burnout syndrome in doctors]. ORGZDRAV: Novosti, mneniya, obuchenie ORGZDRAV: News, opinions, training, 1 (3), 98-106 [in Russian].

26. Usenko, L.V., Kobelyatskiy, Yu.Yu., Klopotskaya N.G., Tsarev, A.V., Usenko, A.A. \& Olenyuk, D.V., (2020). Konfliktnye situatsii v meditsinskoy praktike: eticheskie i pravovye aspekty [Conflict situations in medical practice: ethical and legal aspects]. Meditsina nevidkladnikh staniv - Emergency Medicine, 16, 1, 115-119 [in Ukrainian].

27. Vasilev, V. Yu. \& Pushkarenko, I. A., (2011). Prichiny razvitiya "emotsionalnogo vygoraniya" u anesteziologov-reanimatologov [Reasons for the development of "emotional burnout" in anesthesiologists-resuscitators]. Obshchaya reanimatologiya - General resuscitation, VII, 2, 66-70 [in Russian]. 